\title{
Konsep Pendidikan Anak Prasekolah Dalam Perspektif Ibn Qayyim Al-Jawziyyah
}

\author{
Rosidi $^{1}$ \\ ${ }^{1}$ IAIN Syaikh Abdurrahman Siddik Bangka Belitung
}

\begin{tabular}{ll}
\hline \hline Info Artikel : \\
\hline & \\
Diterima & $:$ 10 Maret 2019 \\
Direvisi & $:$ 12 Juni 2019 \\
Dipublish & $:$ 28 Juni 2019
\end{tabular}

\begin{abstract}
ABSTRAK
Peran edukatif keluarga (orang tua) telah melemah dikarenakan melilitnya persolanaan ekonomi, derasnya pengaruh budaya dan kerasnya perubahan sosial politik yang menggeser tata nilai, watak dan perilaku dalam pola hidup yang tidak berpihak pada kenyamanan anak-anak. Tulisan ini akan mengulas tentang konsep ajaran Islam terhadap pentingya pendidikan anak usia dini dan usia prasekolah melalui pemikiran seorang tokoh muslim Ibn Qayyim AlJauziyah. Ibn Qayyim Al-Jawziyyah merupakan sosok yang memiliki kematangan berfikir dan berkarya, karena ia berguru dan bergaul dengan komunitas yang memiliki etose keilmuan yang sangat tinggi dan diketahui kecemerlangan pikirannya. Pemikiran Ibn Qayyim tentang pendidikan anak usia prasekolah diarahkan pada upaya menyelamatkan fitrah dan potensi dasar yang dimiliki anak.; Pertama, aspek mental-spiritual (al-Tarbiyyah alImaniyah), Kedua, aspek moral (al-Tarbiyah Khuluqiyah) Ketiga, aspek fisik (Tarbiyah Jismiyah) Keempat, Aspek sosial (al-Tarbiyah al-Ijtimaiyyah) diperlukan dalam menata lingkungan yang kondusif untuk mendukung perkembangan anak ke arah yang baik. Kelima, aspek Intelektual.
\end{abstract}

\section{Kata Kunci: \\ Peran Edukasi \\ Aspek mental-spiritual \\ Aspek sosial}

Keyword :

The role of education

Mental spiritual aspects

Socials aspects

\begin{abstract}
The educative role of the family (parents) has weakened because of the twisting of economic polity, the swift influence of culture and the harshness of socio-political changes that shift values, character, and behavior in lifestyles are not in favor of the comfort of children. This paper will review the concept of Islamic teachings on the importance of early childhood education and preschool age through the thought of a Muslim leader Ibn Qayyim Al-Jauziyah. Ibn Qayyim Al-Jawziyyah is a person who has the maturity to think and work because he studied and mingled with communities that have a very high scientific ethos and are known for the brilliance of his mind. Ibn Qayyim's thoughts about the education of preschool children are directed at efforts to save the nature and basic potential possessed by children; First, mental-spiritual aspects (al-Tarbiyyah al-Imaniyah), Second, moral aspects (al-Tarbiyah Khuluqiyah) Third, physical aspects (Tarbiyah Jismiyah) Fourth, social aspects (al-Tarbiyah alIjtimaiyyah) are needed in managing the environment conducive to supporting the child's development in a right direction. Fifth, Intellectual aspects.
\end{abstract}

This is an open access article distributed under the Creative Commons Attribution License, which permits unrestricted use, distribution, and reproduction in any medium, provided the original work is properly cited. 02019 by author.

\section{Koresponden:}

Rosidi

Email: rosidi@gmail.com

\section{Pendahuluan}

Kebanyakan orang tua (pendidik) terutama yang mempunyai pengetahuan minim tentang pertumbuhan dan perkembangan jiwa anak, tidak menganggap penting bahkan meremehkan masa-masa emas dari usia perkembangan anaknya (usia dini dan prasekolah). Demikian juga mereka yang sibuk dan menyerahkan anaknya ke tangan pembantu. Anak-anak dibiarkan begitu saja, tanpa diberikan stimulasi edukatif yang dapat merangsang perkembangan otak dan kreativitasnya, sehingga tidak sedikit anak-anak yang tidak mendapatkan layanan pendidikan di awal usianya, dan pada gilirannya dapat menghambat perkembangannya ketika masa sekolah dikemudian hari, tidak dapat mengikuti pelajaran dengan baik, bahkan cenderung terbelakang (Badu, 2012).

Peran edukatif keluarga (orang tua) telah melemah dikarenakan melilitnya persolanaan ekonomi, derasnya pengaruh budaya dan kerasnya perubahan sosial politik yang menggeser tata nilai, watak dan perilaku dalam pola hidup yang tidak berpihak pada kenyamanan anak-anak. Keluarga telah kehilangan fungsinya dalam pendidikan. Tidak seperti fungsi keluarga pada masa lalu yang merupakan satu kesatuan 
produktif sekaligus konsumtif. Ketika kebijakan ekonomi pada zaman modern sekarang ini mendasarkan pada aturan pembagian kerja yang terspesialisasi yang lebih ketat, maka sebagian tanggung jawab keluarga beralih kepada pemenuhan ekonomi di luar rumah yang sebagian besar waktunya dihabiskan untuk kepentingan pemerolehan hal-hal ekonomis tersebut (Badu, 2011).

Keadaan ini memiliki andil yang besar terhadap tergesernya hak-hak anak dari orang tua yang seharusnya bertanggung jawab membimbing dan mendidik anak-anak. Anak-anak dianggap sebagai makhluk nomor dua, dibanding dengan besarnya kepentingan,dan gemerlapnya kehidupan orang dewasa. Disinilah kita menjadi sadar bahwa anak-anak terutama di masa awal perkembangannya (usia dini dan prasekolah) mengalami kerugian besar dalam hal mendapatkan layanan pendidikan dan memperoleh kasih sayang yang memadai. Padahal orang tua adalah pusat kehidupan ruhani anak sebagai penyebab berkenalannya dengan alam luar. Maka setiap reaksi emosi anak dan pemikirannya di kemudian hari selalu terpengaruh oleh sikap orang tuanya terhadap dirinya di permulaan hidupnya (PAI, 1998).

Sukses tidaknya pendidikan anak kemudian sangat tergantung pada sejauh mana peran orang tua dalam membantu dan membimbing anak dalam sebuah proses perkembangan dan adaptasi dengan lingkungannnya. Lingkungan yang dimaksud dalam hal ini adalah mencakup segala sesuatu yang dapat mempengaruhi seluruh kemampuan dasar dan potensi-poetensi yang dimiliki anak (Laela, n.d.). Dengan demikian, pendidikan anak usia dini dan prasekolah sangat tergantung pada bagaimana keluarga dan lingkungannya (kedua orang tua) dapat mempengaruhi dan membentuk kepribadian, perilaku, dan kecenderungannya secara maksimal sesuai dengan bakat yang ada dalam dirinya (PAI, 1998). Karena pengaruh paling kuat dan cukup langgeng pada diri anak adalah peristiwa dan pengalaman yang terjadi pada masa kecil sang anak terutama dari suasana keluarga yang ia tempati. Seorang anak akan menyerap pola perilaku yang umum berlaku di mana ia berada, kemudian mengkristal dan teraktualisasi dalam bentuk tingkah laku dan kepribadianya sendiri(Smith \& Raeper, 2000).

Para ahli pendidikan telah menyepakati pentingnya periode kanak-kanak dalam hidup manusia. Beberapa tahun pertama pada masa kanak-kanak merupakan kesempatan yang paling tepat untuk membentuk kepribadian dan mengarahkan berbagai kecenderungan ke arah yang positif(Eprilia \& Prasetyarini, 2010). Karena pada periode tersebut kepribadian anak mulai terbentuk dan kecenderungankecenderunganya semakin tampak. Masa kanak-kanak ini juga merupakan kesempatan yang sangat tepat untuk membentuk pengendalian agama, sehingga sang anak dapat mengetahui, mana yang diharamkan oleh agama dan mana yang diperbolehkan(Keerthi \& Lin, 2003).

Beranjak dari hal tersebut di atas, tulisan ini mengulas tentang konsep ajaran Islam terhadap pentingya pendidikan anak usia dini dan usia prasekolah melalui pemikiran seorang tokoh muslim Ibn Qayyim AlJauziyah. Ibnu Qayyim Al-Jauzy sebagaimana dikatakan oleh Usman Nadjati (Murni, Nurul Yusra, \& Solfitri, 2010) adalah salah seorang ulama besar yang pemikiran-pemikirannya banyak berkaitan dengan psikologi dan tentu saja pendidikan, termasuk di dalamnya adalah tentang bagaimana anak-anak yang suci, bersih dan keberadaannya diamanatkan oleh Allah SWT, dididik dan diarahkan perkembangannya ke arah yang baik dan berguna bagi kehidupannya kelak. Ide-ide dan pandangan Ibn Qayyim Al-Jauzyyah adalah salah satu hazanah yang perlu dan menarik untuk diulas dengan mempertimbangkan antara lain: 1) ia adalah tokoh yang hidup pada abad yang diklaim oleh sejarah sebagai abad kejumudan dan stagnasi pemikiran, 2) ia telah menulis buku tentang anak yang berjudul Tuhfatu al-Maudud bi Ahkamal-Maulud. Meskipun kitab ini tampak menggunakan pendekatan hukum (fikih), namun ada beberapa hal yang berkaitan dengan psikologi anak dan secara umum merupakan pemikiran Ibn Qayyim Al-Jauzyyah tentang pentingnya pendidikan anak.

\section{Pembahasan}

\section{A. Riwayat Hidup Ibn Qayyim Al-Jawziyyah}

Ibn Qayyim Al-Jauzyah adalah seorang ahli fiqh, Muhaddits, Mufassir, ahli Nahwu, Ushuli dan Mutakallim yang hidup pada abad 8 H/13 M. Nama lengkapnya adalah Abu Abdillah Syams al-Din Muhammad Ibn Abi Bakr Ibn Ayyub ibn Sa'ad Ibn Harits Ibn Makkiy Zany al-Din al-Zur'iy alDimasyqy. Ibnu Qayyim lahir pada tanggal 7 Safar tahun 691 H bertepatan dengan 29 Januari $1292 \mathrm{M}$ di Azra, salah satu desa di Damaskus (Hasyim, 2005). Kelahiran Ibn Qayyim Al-Jawziyyah (1292$1350 \mathrm{M}$ ), hanya berselang 35 tahun dari tragedi jatuhnya kota Baghdad oleh serangan tentara Mongol yaitu tahun $(1258 \mathrm{M})$. Secara umum dunia Islam saat itu masih merasakan dampak negative akibat serangan tersebut, terutama dalam bidang tatanan politik dan keilmuan. Betapa tidak, serangan yang dipimpin Hulagu Khan itu, tidak saja menghancurkan dominasi kekuatan politik Islam, tetapi juga telah menghancurkan khazanah umat Islam dengan pembunuhan para Ulama dan pemusnahan karya- 
karya Islam yang ada di Baghdad (Abidin, Ushuluddin, \& Antasari, 2009). Pada hal saat itu Baghdad merupakan pusat kebudayaan dan peradaban Islam yang sangat kaya dengan khazanah Ilmu pengetahuan. Sehingga menurut Badri Yatim, jatuhnya Baghdad saat itu bukan saja mengakhiri khalifah Abbasiyah, tetapi juga merupakan titik awal dari masa kemunduran politik dan peradaban Islam (Mujahidin, 2019).

Di bidang peradaban, pemikiran Islam secara umum saat itu memasuki masa stagnan, dan umat Islam sedang terpuruk dalam dunia pemikiran yang ditandai dengan menurunnya produktivitas bidang pemikiran yang bersifat penemuan dan ijtihad baru, dan bahkan dipenuhi oleh kegiatan taqlid kepada para Imam Madzhab. Meskipun Pemerintahan Islam masih berlanjut sampai berakhirnya pemerintahan Turki Usmani, namun secara umum dalam bidang ilmu pengetahuan, umat Islam mengalami kemunduran. Umat Islam ketika itu kurang tertarik kepada sains, sebagaimana umat Islam pada masa sebelumnya. Periode ini terjadi antara tahun 1250-1800 $\mathrm{M}$ yang disebut zaman pertengahan. Perkembangan ilmuwan Muslim saat itu relative sedikit, di antaranya terdapat Ibn Taimiyah dan Ibn Qayyim Al-Jawziyyah(Daya, 1990).

Prestasi dalam bidang keilmuan pada masa Ibn Qayyim Al-Jawziyyah, tidak sehebat yang berkembang pada masa-masa sebelumnya. Ulama yang mencapai derajat mujtahid tidak sebanyak masa yang dahulu. Mereka umumnya tidak membuat rumusa-rumusan ijtihad yang baru, melainkan hanya mereduksi pemikiran-pemikiran yang ada. Dalam bidang kajian agama, mereka dicukupkan dengan membaca karya imam-imam terdahulu. Apa yang dipelajari di masjid-masjid, madrasahmadrasah, tempat-tempat pendidikan dan kajian-kajianpun, tidak lagi bersifat penemuan dan pengembangan, melainkan sebatas memahami karya-karya ulama pendahulunya. Bila dilihat dari periodisasi pendidikan Islam, Ibn Qayyim Al-Jawziyyah hidup pada era pendidikan Islam sedang mengalami kemunduran. Periode ini berlangsung sejak jatuhnya Baghdad sampai jatuhnya Mesir ke tangan Napoleon yang ditandai dengan runtuhnya sendi-sendi kebudayaan Islam dan berpindahnya pusat-pusat kebudayaan ke dunia Barat.

Ibn Qayyim Al-Jawziyyah sebagai ulama yang cerdas dan memiliki etos keilmuan yang tinggi di zamannya, menjadikan ia lebih banyak mengabdikan dirinya dalam hal-hal yang terkait dengan ilmu pengetahuan. Selama hidupnya ia dikenal sebagai imam tetap di madarasah al-Jawziyyah, sekali gus sebagai pengajar.Madrasah ini menjadi masyhur karena peranannya yang besar dalam penyebaran dan pengembangan ilmu pengetahuan, sehingga memberi kehidupan yang terhormat kepada para pengasuhnya di mata masyarakat. Di samping itu, ia juga pengajar di madrasah al-Shadriyyah yang didirikan oleh Shadr al-Din as-Sa'ad Ibnu Nu'man Ibn al-Manja (wafat 657 H)(Abdullah, 2010). Ibn Qayyim Al-Jawziyyah meninggal dunia setelah shalat Isya, tepatnya pada hari Rabu malam Kamis, tanggal 13 Rajab $751 \mathrm{H} / 1350 \mathrm{M}$ dalam usia 60 tahun di Damaskus. Ibn Qayyim Al-Jawziyyah dikebumikan di Bab al-Shaghir atau semacam makam keluarga(al-Jawziyyah, n.d.).

\section{B. Riwayat Pendidikan Ibn Qayyim Al-Jauzyyah}

Ibn Qayyim Al-Jawziyyah berasal dari keluarga yang kental dengan nuansa keilmuan, terhormat dan mapan secara ekonomis. Ayahnya Abu Bakar Ibnu Ayyub al-Zur'iy dikenal sebagai seorang faqih dari mazhab Hambali dan ahli ilmu faraidh, yang berprofesi sebagai guru kemudian menjadi pimpinan di Madarah Al-Jawziyyah. Dengan meminjam teori aliran nativisme yang menentukan perkembangan tingkah laku seseorang berasal dari peranan sifat bawaan, keturunan dan hereditas (heredity), maka Ibn Qayyim Al-Jawziyyah merupakan sosok yang memiliki garis keturunan yang baik, sebab bapaknya adalah pendiri dan pengurus sekolah al- Jauziyyah yang berada di Damaskus. Jika seorang bapak konsern terhadap persoalan pendidikan dalam hidupnya, maka tak mengherankan jika sang anak memiliki darah dan bakat yang berhubungan dengan pendidikan(Rajab, 1961).

Pada tahap awal, Ibn Qayyim Al-Jawziyyah belajar beberapa ilmu yang menjadi keahlian ayahnya kemudian melanjutkannya di madrasah. Hal ini disebabkan karena kegiatan intelektual pada masa itu secara umum berpusat di madrasah-madrasah,masjid-masjid, khanqah-khanqah (Nurlela, 2009) dan ribath-ribath(Jamaludin \& Ramli, 2013). Ibn Qayyim Al-Jawziyyah memulai pendidikannya di madarasah al- Jawziyyah di bawah pengawasan langsung dari ayahnya yang ketika itu adalah pengelola madarasah tersebut. Al-Jawziyyah adalah nama sekolah di Damaskus yang dibangun oleh seorang yang dikenal dengan nama Abdurrahman al-Jawzy. Madarasah ini merupakan salah satu madarasah Hambaliyyah terbesar di kota Damsyik ketika itu. Selanjutnya ia pernah melakukan rihlah ilmiyah ke Mesir dan ke Mekkah(Katsir, 1996).

Kedudukannya sebagai putra pendidik membuatnya sangat mencintai ilmu sejak masa mudanya, sehingga berbagai macam disiplin ilmu agama ia kuasai. Ibn Qayyim Al-Jawziyyah berguru kepada as- 
Syihab al-Nabulsi al-Aibar, Abu Bakar bin al-Dayim, al-Qadhi Taqiyyuddin Salman, Isa al-Muth'im, Fathimah binti Jawhar, Abu

Nashar Muhammad bin Imaduddin al-Syarazy, Ibn Maktum al-Bahaa bin al-Syakir, al-Qadhy Badr al-Din bin Jamaah dan lain-lainnya(Fauzan, 2015).

Ia belajar bahasa Arab kepada Abu al-Fath al-Ba'labaky (wafat $709 \mathrm{H}$ ) belajar al-Mulakhas kepada Abu al-Baqa, belajar kitab al-Fiyyah kepada Ibn Malik (wafat $1273 \mathrm{M}$ ), belajar al-Muqarrab kepada Syekh Majduddin al-Tunisi, belajar fiqh kepada Syekh Ismail bin Muhammad al-Harraniy (wafat 729 H). Lalu belajar mukhtashar al-harqy dan al-Muqanni', kepada Ibnu qudamah, belajar ilmu faraidh dari ayahnya dan dilanjutkankepada Ismail bin Muhammad, belajar ilmu Ushul kepada Syekh Syafiuddin al-Hindy. Sedangkan guru yang paling berpengaruh kepada dirinya dan ia selalu berada disisinya untuk menggali ilmu selama hidupnya adalah Syekh 'Allamah Taqiyuddin Ibn Taimiyah wafat 729 H, kepadanya Ibn Qayyim Al- Jawziyyah belajar kitab al-Mukharrar, ilmu faraidh, kitab alMahshul dan kitan al- Ahkam(Fauzan, 2015). Di antara semua guru Ibn Qayyim Al-Jawziyyah, Syekh Ibn Taimiyah adalah yang paling berkesan dan banyak membentuk sikap ilmiyah dan pribadinya, dan merupakan profile yang diidolakan olehnya.

Sebagai ulama besar yang memiliki kepedulian dan tanggung jawab tinggi untuk meyebarkan ilmu, Ibn Qayyim Al-Jawziyyah menerima banyak orang yang datang untuk berguru kepadanya. Di antara tokoh saat itu yang pernah berguru kepada Ibn Qayyim Al-Jawziyyah adalah anaknya sendiri, Abdullah bin Syamsuddin yang pernah memimpin sekolah al-Shadariyyah setelah wafatnya Ibn Qayyim Al- Jawziyyah. Juga terdapat nama Ibn Rajab (pengarang kitab al-Dhail al-Madzahib alHanabilah), Ibnu Katsir pengarang kitab al-Bidayah wa al-Nihayah), Syamsuddin al- Nabilsi (pengarang kitab Mukhtashar Thabaqat Hanabilah) dan tokoh-tokoh madzhab Hanbali lainnya(Fauzan, 2015).

Dari pemaparan tentang biografi pendidikan di atas, sangatlah beralasan jika dikatakan bahwa Ibn Qayyim Al-Jawziyyah adalah seorang ulama besar yang memiliki keluasan ilmu dan ketajaman pikiran. Hal tersebut tentu saja karena dilatar-belakangi oleh perjalanan study yang memadai dan dikelilingi komunitasnya oleh ulama-ulama besar dan komunitas pendidikan yang mendukung. Sehingga orientasi dalam hidup dan kehidupannya tidak pernah lepas dari suasana keilmuan. Dari hal tersebut yang tidak kalah urgen adalah betapa orang tua Ibn Qayyim menaruh perhatian yang sangat baik dan maksimal terhadap perkembangan dan pola pendidikan dini terhadap tumbuh kembang pendidikan dan karakter Ibnu Qayyim kecil sehingga membawa Ibn Qayyim menjadi anak yang tumbuh berkembang di lingkungan yang selalu haus akan pencarian ilmu pengetahuan. Hal inilah yang kemudian menjadi salah satu karakter khusus pola pendidikan anak pra sekolah yang menjadi focus tulisan ini.

\section{Karya-karya Ibn Qayyim Al-Jawziyyah dan Karakteristik Pemikirannya}

Ibn Qayyim Al-Jawziyyah, adalah profile ulama yang sangat produktif. Semasa hidupnya ia menorehkan karya-karya monumental dalam berbagai disiplin ilmu pengetahuan. Ia mengeluti berbagai bidang ilmu pengetahuan terutama tafsir dan ilmu-ilmu qulub.

Ibn Qayyim Al-Jawziyyah merupakan sosok yang memiliki kematangan berfikir dan berkarya, karena ia berguru dan bergaul dengan komunitas yang memiliki etose keilmuan yang sangat tinggi dan diketahui kecemerlangan pikirannya. Ibn Qayyim Al-Jawziyyah, berkeinginan menyebarkan ilmu (nasyr al-Ilmi) dan berbuat sesuatu yang bermanfaat bagi kaum Muslimin. Oleh karena itu, ditemukan banyak sekali hasil karya tulisnya, sebagai buah pikiran dan kontribuasinya dalam menata umat Islam saat itu.

Karya-karya Ibn Qayyim Al-Jawziyyah meliputi berbagai bidang ilmu antara lain: Tafsir, Fiqh, Hadits, Ilmu Kalam, Tasawwuf, Sejarah dan juga Kimia. Di antara karya-karya Ibn Qayyim AlJawziyyah yang terkenal adalah: Bidang Tafsir: Tafsir al-Qayyim (satu Jilid), al-Tibyan Fi Aqsam alQur'an, Tafsir al-Fatihah, Tafsir al-Mu'awwidzatain dan Usdhul al-Tafsir. Bidang Hadits: Hadits alManar al-Munif fi al-Shahih wa al-Dhaif, Tahdzib al- Sunnah abi Dawud, Al-Wabil al-Shayyib min Kalam al-Thayyib, dan al-Da'I ila Asyarf al-Masa'i. Bidang Fiqh dan Ushul Fiqh: I'lamal-Muwaqqi'in an Rabb al-'Alamin (4 Jild), Al-Shalat wa Ahkam Tarikhiha, Jawab al-Kafi Liman Saal 'an al-Dawa alSyafi, Tuhfat al-Wadud bi akhkam al-Maulud, Hukmu Ighmami Hilali Ramdhan, Nikah al-Muhrim, Rafu al-Yadain fi as-Shalah, bayan al-Dalil 'ala Istghnai al-Musabaqah 'an al-Tahlil, Al-Thuruq alHukmiyyah fi al-Siyasah al-Syar'iyyah dan al-Tahlil fi Maa Yahillu waYahrimu min Libas al-Harir. Bidang Ilmu kalam/ Teologi dan filsafat: Miftah dar al-Sa'adah, Syifa al-'Alil fi al-Qadha wa al-Qadar wa al-Hikmah wa al-Ta'lil, Ijtima' al-Juyus al-Islamiyah 'ala Ghawz al-Muattilah wa al-Jahmiyyah, al_kafiyah fi al-Intishari al-Firqah al- Najiyah, Hadi al-Arwah ila bilad al-Afrah, Al-Ruh, Al-Ilmu, Al- 
Syifa Ahlu al-Nar dan Ighatsah al-Lugfan min Masyayid al-syaithan, Ighatsah al-Lugfan fi Hukmi Talak al-Ghadhban.

Bidang Tasawwuf: Madarij al-Shalikhin: Bain al-Manazil Iyyaka na'budu wa Iyyaka Nastain, Raudhat al-Muhibbin wa Nasyat al-Mustaqin, Hikmat al-Ibtila, Syarh Asbab al-'Asyrah al-Muwajibat li Mahbbah lillah, Makayid al-Syayathin fi al-Waswasati wa Dzammu al-Muwaswisin, 'Uddat alShabirin wa Dzakiraty asy- Syakirin, al-Wabil al-Shayyib min kalam al-Thayyib, Bada'u al-Fawaid, Alfawaid, Dzakirah asy-Syakirin dan Thariq al-hijratain wa bab al-Sa'adatain. Bidang Sejarah: Akhbar al-Nisa dan Zad al-ma'ad fi Hadyi Khair al-Ibad. Bidang Kimia: Buthlan al-Kimiya min Arba'i Wajhan.

Dalam menulis karya-karyanya, gaya penulisan (metodologi penulisan dalam istilah sekarang), Ibn Qayyim Al-Jawziyyah memiliki karakteristik ciri yang nyata dan jelas, sebagaimana yang dilakukan oleh gurunya, Ibn Taimiyah. Misalnya, seluruh karya Ibn Qayyim Al-Jawziyyah ditulis dengan menggunakan pendekatan deduktif yaitu bahwa kerangka berfikir yang digunakannya semua bersumber dan bermuara pada nash-nash ilahy, al-Qur'an, Sunnah dan juga fatwa-fatwa shahabat, bukan berdasarkan aktivitas observasi, eksperimen atau metode ilmiyah lainnya (induktif). Secara umum, karaktersitik dan ciri-ciri ini telah menjadi metodologi yang dipergunakan oleh para eksponen madzhab salafiyah yang dipelopori oleh pendahulunya, Imam Ahmad bin Hanbal dan Ibn Taimiyah.

Adapun karakteristik pemikiran Ibn Qayyim yang terpenting adalah sebagai berikut: (Nurhaeni, 2008) Sikapnya yang kuat terhadap al-Qur'an dan Sunnah Metode ini bersandar pada prinsip-prinsip dasar pola berfikir Imam Amad bin Hanbal yang tidak pernah mendahului al-Qur'an dan Hadits Shahih. Jika didapatkan hadits Shahih dalam hal apapun, maka beliau tidak mendahulinya. Jika hanya menemukan hadits dhaif dan tidal ada yang menentangnya, maka beliau menggunakan hadits itu.

Mengutamakan aqwal Shahabah di atas pendapat selain mereka. Penetapan aqwal shahabah (pendapat para sahabat) sebagai rujukan Ibn Qayyim Al-Jawziyyah setelah al-Qur'an dan Sunnah, karena para sahabat memiliki keunggulan dalam sifat-sifat serta pengetahuan-pengetahuan dalam tarjih (pengutamaan) pendapat dan pengumpulan hukum-hukum. Menurut Ibn Qayyim Al- Jawziyyah, para sahabat diberi keistimewaan oleh Allah SWT dengan kejernihan pikiran, keluasan pengetahuan, kemudahahan penerimaan, kecepatan pemahaman, kebaikan tujuan, serta mampu menangkap dan mengungkap makna-makna simbol ajaran agama dan analogi-analogi yang belum tentu dapat dilakukan oleh orang selain sahabat. Imam Ahmad ibn Hanbal mengatakan, mencintai sahabat adalah sunnah, mendoakan mereka adalah ibadah, mengikutinya adalah cara yang benar dan memakai pendapat-pendapatnya adalah suatu kemuliaan.

Totalitas dan menyeluruh. Dalam membahas suatu masalah, Ibn Qayyim Al-Jawziyyah meninjaunya dari berbagai segi, mengemukakan pandangan berbagai golongan terhadap masalah yang dibahas, membahas dalil-dalil mereka secara tematis, mengkritisi pendapat-pendapat mereka, dan memetakan pendapat yang sesuai dengan akal dan nalar dalam pandangannya. Beliau melarang sikap taqlid dan ta'ashub kepada pendapat dan pemikiran ulama. Beliau berkata: "Kita berpaling dari ta'ashub kepada ulama, kita memilih pendapat mereka yang sesuai dengan kitabullah dan Sunnah Rasulullah. Dengan keduanya kita menerima pendapat mereka dan bukan karena salah seorang dari mereka, siapapun dia. Kita tidak mengatakan benar atau salah terhadap pendapat seseorang kecuali berdasarkan al-Qur'an dan Sunnah, kemudian kita mengikuti pendapatnya tanpa sedikitpun bimbang kepadanya. Kemudian kita mengharakan mengikuti selainnya dalam hal-hal yang menyalahi al-Qur'an dan Sunnah. Demikian para Imam yang shalih berwasiat kepada kita dan dengan ini mereka membai'at kita. Makadengan hal itu kita bermanhaj dan di atas jalan dan petunjuknya kita berjalan."(Tanjung, 2011)

Sikap Ibn Qayyim Al-Jawziyyah seperti tersebut di atas menunjukkan betapa kuatnya prinsip beliau dalam berpegang teguh dengan al-Qur'an dan Sunnah serta prinsip-prinsip kebenaran yang berasal dari wahyu dan logika yang sehat. Seakan menegaskan kepada umat Islam agar terbebas dari kurungan hawa nafsu dan bergantung berlebihan terhadap pendapat leluhurnya.

Ibn Qayyim Al-Jawziyyah dan Pendidikan Anak Prasekolah

Pemikiran Ibn Qayyim Al-Jauzyyah tentang pendidikan anak terutama mengenai anak usia dini dan prasekolah, bermuara dari pemikirannya yang luas tentang konsep manusia dan pendidikan secara umum. Tentu saja corak pemikirannya tidak dapat dilepaskan dari latar belakang kehidupan dan proses pendidikannya. Oleh karena itu sebelum pembahasan ini sampai pada pemikiran Ibn Qayyim Al-Jauzyyah sesuai dengan tema yang dimaksud, penulis menganggap penting untuk mengungkap lebih luas hasil penelitian tentang beberapa pandangan Ibn Qayyim al-Jauzyyah mengenai konsep manusia dan pendidikan. 
1. Eksistensi Manusia menurut Ibn Qayyim Al-Jauzyyah

Pandangan Ibn Qayyim Al-Jauzyyah tentang pendidikan anak bermuara pada pandangannya tentang hakekat manusia terutama pandangannya yang luas tentang hubungan ruh dan badan dalam hidup dan kehidupan manusia. Menurut Ibn Qayyim Al-Jauzyyah, hakekat manusia merupakan perpaduan yang terdiri dari beberapa unsur yang saling berkaitan dan tidak mungkin dipisahkan antara satu dan lainnya. Hal ini dapat dilihat dari salah satu pernayataannya, beliau berkata, "Sesungguhnya hakekat eksistensi diri manusia itu ada pada ruh dan hatinya bukan pada jasad dan badannya." Ibn Qayyim Al-Jauzyyah dalam manhaj tarbiyahnya memandang hakekat manusia secara utuh, sempurna dan menyeluruh. Manusia dalam pandangannya adalah perpaduan antara ruh, akal dan jasad.(Tanjung, 2011)

Selanjutnya, Ibn Qayyim Al-Jauzyyah mengatakan "Sesungguhnya Allah telah memadukan tiga unsur dalam jiwa manusia yaitu: unsur kekuatan, syahwat dan unsur iradah. Perpaduan tiga unsur ini akan membentuk sebuah kekuatan yang dapat meggerakkannya untuk senantiasa berusaha mencari hal-hal yang bermanfaat bagi dirinya dan menghindari setiap yang membahayakan jiwanya atau jiwa orang lain yang telah membantunya". Menurutnya ruh memiliki hubungan yang erat dengan badan, sehingga kehidupan badan sangat terikat dengan ada atau tidaknya ruh di dalamnya. Apabila ruh ini lepas darinya, maka badan tersebut akan kehilangan kehidupannya. Dengan adanya keterikatan dan hubungan yang erat ini menjadikan ruh sebagai benda asing sendiri dan terpisah dari yang lainnya. Demikian itu karena hakekat manusia bukan hanya terdiri dari unsur badan saja yang tidak ada kaitannya dengan unsur ruh dan akal. Atau sebaliknya. Tetapi hakekat manusia itu adalah satu bangunan yang terpadu, yang di dalamnya terdapat beberapa unsur yang saling berkaitan.

Ibn Qayyim Al-Jauzyyah menilai bahwa Ruh berada dalam badan laksana orang mukmin di sebuah negeri yang asing, Karena ia memiliki negeri sendiri (bukan badan) dan tentu ia tidak akan mau menetap kecuali di negerinya sendiri. Tetapi ruh ini dipakasa untuk untuk bertempat tinggal dalam badan manusia yang tebal ini, sehinga ia tetap mencari tempat tinggal yang tinggi yang sealalu ia rindukan, sebagaimana rindunya burung kepada sarangnya.(Tanjung, 2011)

Begitulah hakekat keterkaitan antara ruh dan badan yang tidak mungkin dapat dipisahkan karena ikatan yang mengikat keduanya sangat kuat dan antara keduanya saling berpengaruh. Oleh sebab itu, ketika ruh hendak berpisah dari jasad, dikatakan kepadanya, "wahai jiwa yang baik, yang bertempat di jasad yang baik keluarlah kamu darinya," atau "wahai ruh yang buruk yang bertempat di jasad yang buruk keluarlah kamu.(Tanjung, 2011)

Padangan Ibn Qayyim Al-Jauzyyah tentang manusia didasarkan pada paradigma intuitif dan wahyu yang tidak memisahkan antara realitas fisik dan metafisik, serta antara yang profane dan transenden. Konsep-konsep Ibn Qayyim Al- Jauzyyah adalah hasil kerja intuisi atau hasil perenungan terhadap ayat-ayat al-Qur'an dan Sunnah, dua sumber utama ajaran Islam. Ia memandang bahwa manusia mempunyai potensi-potensi sebagai berikut: a). Manusia sebagai makhluk potensial, berupa ilmu, akal dan kemampuan menganalisa. b). Manusia memiliki kecenderungan berbuat baik c). Manusia mempunyai motivasi untuk bekerja dan beribadah, d). Manusia mempunyai kemampuan untuk belajar. Sehingga dengan demikian ia memandang bahwa ada unsur internal (ruh, dawafi) dan unsur eksternal (lingkungan) yang berpengaruh dalam proses pendidikan manusia.(Tanjung, 2011)

Ibn Qayyim Al-Jauzyyah memandang manusia adalah objek kerja pendidikan (tarbiyah), sehingga pendidikan yang berhasil dapat menjadikan manusia mampu mewujudkan tujuan penciptaannya. Manusia diciptakan agar mengetahui hakekat Tuhannya, kemudian meng-esakanNya, memurnikan ibadah, kembali dan bertawakkal kepada-Nya, mengikhlaskan amal, cinta dan ridha kepada-Nya, menjalankan seluruh perintah dan menjauhi semua larangan-Nya. Tujuantujuan ini, kemaslahatannya tidak kembali kecuali untuk manusia sendiri.(Tanjung, 2011)

Dengan demikian, tujuan utama penciptaan manusia adalah untuk beribadah kepada Allah semata dan beribadah kepada Allah itu menuntut adanya ilmu tentang hakekat-Nya, berupa ilmu mengenai asma, sifat, perintah dan seluruh larangannya. Menurut Ibn Qayyim ibadah menuntut kepada dua dasar utama: pertama, kecintaan kepada Allah dan kedua, kerendahan diri dan ketundukan kepada-Nya. Siapa yang mencintai Allah tetapi tidak patuh dan tunduk kepadaNya, berarti ia belum menjadi hamba-Nya. Dan sebaliknya siapa yang tunduk kepada Allah tetapi tidak cinta kepada-Nya, maka iapun belum dikatakan hamba-Nya. Dan seseorang akan benar- benar 
menjadi hamba Allah jika ia telah memadukan dalam dirinya antara kecintaan dan ketundukan kepada-Nya.(Tanjung, 2011)

Kecintaan dan ketundukan manusia terhadap Tuhannya, demikian juga kebutuhannya terhadap nilai-nilai kebaikan dan kebahagiaan, sebenarnya adalah fitrah dasar penciptaan manusia. Manusia dalam pandangan Ibn Qayyim Al-Jauzyyah diciptakan oleh Allah dalam keadaan suci dan selamat dari penyimpangan dan inilah yang dikatakan fitrah Allah Ta'ala yang dijadikan dasar penciptaan manusia. Dari hasil tela'ahnya terhadap sabda Rasulullah tentang kesucian fitrah anak manusia, ia menyimpulkan, bahwa setiap manusia (bayi) itu dilahirkan dalam keadaan fitrah mencintai penciptanya, mengakui ketuhanan-Nya, tunduk kepada-Nya. Hal ini sebagaimana ketia ia dilahirkan, ia membawa fitrah (naluri) mencintai tiap apa yang dibutuhkan oleh tubuhnya berupa makanan dan minuman, sperti bagaimana senangnya seorang bayi mengisap air susu ibunya yang memang mengandung gizi dan dzat yang dibutuhkan untuk kesehatan tubuhnya.(Arif, 2010)

Dengan demikian fitrah manusia yang suci itu memiliki kesiapan untuk menampung berbagai bentuk kebaikan dan dengan mudah menerima apa yang diajarkan dalam pendidikan berupa nilainilai kemuliaan dan akhlak. Semua ini menunjukkan bahwa fitrah manusia benar-benar bersih dan suci(Aprianti, 2016). Maka pendidikan yang baik ialah yang mampu mengukir semenjak lembaran awal jiwa manusia, nilai nilai kebaikan dan kebahagiaan. Namun menurut Ibn Qayyim, lingkungan yang rusak dan pergaulan yang buruk, akan menodai dan meracuni kesucian fitrah manusia dan menyebabkan munculnya penyimpangan dan penyelewengan terhadap nilai-nilai kebaikan.

Dari penjabaran di atas, dapat digambarkan bahwa Ibn Qayyim Al-Jauzyyah memandang bahwa manusia adalah makhluk yang diciptakan secara sempurna baik ruhani maupun jasmani dengan potensi dasar yang sangat positif (fitrah) yaitu mempunyai kecenderungan men-Tuhankan Allah semata dan merindukan nilai-nilai kebaikan dan kebahagiaan. Disinilah wilayah yang harus dijangkau dan disentuh pendidikan, bahwa tugas pendidikan menurut Ibn Qayyim Al-Jauzyyah adalah menyelamatkan manusia bukan sekedar pada aspek jasmani agar supaya sehat dengan kelengkapan gizi dan terhindar dari berbagai penyakit (tarbiyah badaniyah), tetapi juga mengisi ruh (tarbiyah ruhiyah) dan hati manusia dengan iman (tarbiyah imaniyah) dengan ajaran-ajaran dan nilai-nilai yang menjadi kebutuhan dasarnya secara spiritual, sehingga akan hiduplah kedua unsur yang saling melengkapi itu dalam diri manusia.

Ibn Qayyim Al-Jauzyyah meyakini bahwa pendidikan merupakan kunci terpenting dalam membentuk dan mengantarkan manusia ke pada sebuah kebudayaan yang baik dan bermartabat. Pendidikanlah yang secara mendasar dapat membimbing dan menunjukkan kepada pola sikap dan perilaku yang benar, tepat dan bermanfaat bagi eksistensi hidup manusia di dunia dan untuk kelak hidup di akherat. Pandangannya tentang pendidikan misalnya dalam komentarnya terhadap Ibn Abbas ra $($ w. $68 \mathrm{H})$ tentang kata rabbani yang ditafsirkan dengan makna tarbiyah, beliau berkata: "Tafsiran Ibn Abbas ini dikarenakan bahwa kata tarbiyyah itu merupakan pecahan dari kata rabba yang artinya mendidik manusia dengan ilmu sebagaimana seorangan bapak mendidik anaknya". Selanjutnya beliau mengatakan, kata rabba-yarubbu-rabban artinya mengarah pada seorang pendidik (perawat), yaitu orang yang merawat ilmunya sendiri agar sempurna sebagaimana orang yang merawat hartanya agar bertambah, dan merawat manusia dengan ilmunya sebagaimana seorang bapak merawat anaknya.(Fauzan, 2015) Dalam kontek ini, Ibn Qayyim menegaskan bahwa tarbiyah (pendidikan) adalah proses membentuk, merawat dan mengembangkan potensi manusia secara sungguh-sungguh melalui pembinaan, pengarahan dan teladan yang baik (qudwah). Tanpa pendidikan yang baik melalui pembinaan akhlak anak, kebahagiaan dalam hidup dan kehidupan tidak mungkin dapat diperoleh.(Fauzan, 2015)

Pendidikan mempunyai peranan yang sangat penting dan menentukan bagi perkembangan dan perwujudan diri individu, terutama bagi pembangunan bangsa dan Negara dalam berbagai aspeknya, fisik, intelektual, mental dan spiritual. Kemajuan dan tinginya martabat suatu kebudayaan tergantung kepada cara kebudayaan tersebut mengenali, menghargai dan memanfaatkan sumber daya manusia dan hal ini berkaitan erat dengan kualitas pendidikan yang diberikan kepada peserta didik.(Munandar, 1999)

\section{Konsep Pendidikan Anak Ibn Qayyim Al-Jauzyyah}

Konsep pendidikan anak yang dikemukakan Ibn Qayyim al-Jauzyyah secara umum tertuang dalam karyanya Tuhfatul Maudud bi ahkamil Mulud. Dalam buku ini Ibn Qayyim al-Jauzyyah mengemukakan konsep pendidikan anak yang muaranya di atur oleh tuntunan al-Qur'an dan 
Sunnah. Ibn Qayyim juga menyoroti pentingnya melihat proses perkembangan anak dari waktu ke waktu dan ia memberikan periodisasi pendidikan anak usia prasekolah. Di beberapa kitabnya yang lain, Ibn Qayyim juga menyoroti tentang pentingnya ilmu pengetahuan, pendidikan termasuk di dalamnya peserta didik, guru, materi dan metodenya. Keseluruhan konsep pendidikan Ibn Qayyim al-Jauzyyah ini dapat dikemukakan sebagai berikut.

a. Pandangan Ibn Qayyim tentang Pendidik

Pendidik (guru) dan atau orang tua merupakan elemen pendidikan yang sangat menentukan sukses tidaknya pendidikan untuk anak-anak. Peran dan tanggung jawab pendidik tidak hanya terbatas pada mentransfer ilmu pengetahuan kepada anak didiknya dan tidak pula merasa cukup hanya dengan mengembangkan sisi ilmiah belaka dengan memberikan teori-teori keilmuan, tetapi lebih dari itu, pendidik bertanggung jawab mengawasi, membimbing dan mengarahkan serta memberikan ruang gerak anak-anak untuk dapat mengembangkan kreativitas, potensi-potensi dan kemampuan dasarnya.

Dalam pandangan Ibn Qayyim Al-Jauzyyah pendidik (murabbi) adalah sosok yang seharusnya memiliki akhlak dan perangai yang terpuji dan dapatmenjadi contoh bagi anak didiknya. Memiliki keluasan ilmu dan tentu saja bersikap wira'i dan menjaga diri dari sikap yang tidak terpuji.

Secara umum pemikiran Ibn Qayyim al-Jauzyyah tentang pendidik sangat bersifat normative dan bermuara pada aspek moral yang diperjuangkan oleh golongan salafy. Hal ini dimaklumi karena memang ia adalah seorang murid dari Ibn Taimyyah yang menjadi pioner dari gerakan salafy dan pemurnian ajaran Islam. Pandangannya yang luas dan sangat mendasar tentang pendidik merupakan refleksi dari perhatiannya yang besar terhadap pola-pola pendidikan yang dilakukan oleh para salafus-shaleh dan hasil dari telaah kritis dari pola pendidikan saat itu yang dianggap tidak sesuai.

Ibn Qayyim menegaskan bahwa guru terlebih untuk anak-anak yang sangat memerlukan bimbingan, harus mempunyai karakter sebagai berikut;

Guru tidak berbuat sesuatu yang tidak terpuji, mengotori niat dan menghancurkan kewibawaan dirinya, dengan orientasi yang berlebihan pada kehidupan materi. Ibn Qayyim AlJauzyyah berkata "Imam Ahmad berkata, saya telah berbicara kepada kami, Ja'far telah berbicara kepada kami, saya mendengar Malik bin Dinar berkata,"Takutlah kalian kepada ahli sihir (yaitu dunia), karena ia akan menyihir hati para ulama.(Fauzan, 2015)

Guru yang baik adalah pribadi yang sungguh-sungguh (mujahadah) dalam membimbing dan mengikuti perkembnagan bakat dan potensi anak. Ini harus dibuktikan dengan pemahamannya yang dalam tentang anak itu sendiri, mencakup ilmu perkembangan dan polapola yang benar dalam menumbuh kembangkan kemampuan dasar anak.

Di samping itu, guru anak-anak dalam pandangan Ibn Qayyim perlu mempunyai pemahaman yang mendalam tentang agama dan ketentuan moral yang berlaku dengan keyakinan yang mendalam tentang persoalan spiritual (iman).(Nurhaeni, 2008) Hal ini paling tidak dapat menjadi warna sikap dan jati dirinya, yang kemudian teraktualisasi dalam sikap bijaksana terhadap anak-anak.

Guru yang baik selalu mengetahui kemampuannya dan bijak dalam mendidik anak-anak serta tidak terpengaruh dengan pendapat orang lain. Namun tidak juga bersikap angkuh dan sombong dengan penilaian positif dari orang lain.(Nurhaeni, 2008)

Guru harus mempunyai orientasi yang besar terhadap pengembangan diri, bersikap dinamis dan semangat (ghirah) untuk dapat menambah pengetahuan dan tidak merasa cukup dengan ilmu yang dimilikinya.(Nurhaeni, 2008)

Dalam kontek pendidikan anak prasekolah, Ibn Qayyim secara lebih khusus menyebutkan beberapa sifat dan adab seorang pendidik terhadap anak didiknya sebagai berikut: Bersikap penuh kasih sayang kepada anak-anak, menghibur mereka, menganggap mereka layaknya anak sendiri dan menempatkan dirinya sebagai bapak yang baik, demikian itu dalam rangka menanamkan kepercayaan dan memberikan kebahagiaan serta kesenangan kepada mereka. Hal ini sebagaimana diwasiatkan dan dicontohkan oleh Rasulullah Shallahu 'Alaihi wa sallam, dalammenempatkan dirinya di hadapan anak-anak kecil, ia benar-benar mencerminkan seorang pendidik yang paling agung.

Peran dan tugas seorang pendidik justeru bukan pada bagaimana mentransfer ilmu pengetahuan kepada anak-anak tetapi mengupayakan pengembangan berbagai aspek yang dibutuhkan oleh anak-anak usia prasekolah dan juga bertanggung jawab untuk dapat 
mengawasi, membimbing dan mengarahkan sikap perilaku anak-anak ke arah perkembangan yang harapkan.

Dalam kontek ini pendidik benar-benar bersikap adil kepada anak-anak termasuk dalam memberikan pelajaran, bimbingan dan perhatian. Tidak melebihkan yang satu dan mengurangi yang lainya baik dalam memberikan pelajaran ataupun dalam berinteraksi dan berkomunikasi. Hal ini dimaksudkan agar tidak menimbulkan rasa iri dan kesan negative dalam diri anak-anak. Namun meskipun demikian, seorang pendidik harus cermat dalam mengamati kemampuan yang dimiliki anak-anak untuk kemudian memperhatikan potensi-potensi yang berkembang dan memberinya simulasi yang baik dan adil sesuai dengan kebutuhan perkembangannya.

Seorang pendidik juga harus dapat melihat secara jeli terhadap tanda-tanda kejeniusan dan keberbakatan seorang anak, untuk kemudian memberikan simulasi dan rangsangan yang dapat membangkitkan kemampuan dan kelebihan yang dimiliki itu sesuai arah yang benar.

Seorang pendidik harus tegas dan tidak segan-segan memberi peringatan atau hukuman terhadap anak didiknya yang melakukan kesalahan dan penyimpangan, hal ini sebagai tanggung jawab guru kepada mereka untuk tidak membiarkan mereka melakukan sesuatu yang tidak baik. Tentu saja pemberian hukuman dan peringatan yang dimaksud selalu atas dasar bimbingan dan penuh kasih sayang, dengan cara yang dibenarkan.

Pandangan-pandangan Ibn Qayyim Al-Jauzyyah ini dapat ditarik kesimpulannya dengan sebuah prinsip bahwa tolak ukur keberhasilan pendidikan di antaranya ada pada faktor guru. Pentingnya posisi guru dalam pendidikan, menjadikannya sangat berat tugas dan tanggung jawabnya, baik secara moral, akhlak dan spiritual serta adanya tuntutan kelengkapan dirinya dengan keluasan pengetahuan dan pemahaman tentang ilmu. Pantaslah kemudian Islam memandang sangat mulia kepada mereka yang menjadi guru bagi manusia (pendidik) dan pembimbing ke jalan yang baik dan benar.

Dalam kontek pendidikan anak usia prasekolah sifat-sifat guru (pendidik) yang diungkapkan oleh Ibn Qayyim al-Jauzyyah adalah justeru lebih harus ditekankan penerapannya, mengingat kesalahan sedikit saja keluar dari guru dan pasti akan dirasakan oleh anak-anak, dan itulah yang menjadi cermin pendidikan yang berlangsung dan kemudian secara tidak sadar telah menjadi bagian yang terpatri dalam diri anak.

Pemikiran Ibn Qayyim al-Jauzyyah tentang kualifikasi guru sebagai pendidik ini, sangat relevan bila disandingkan dengan kebutuhan pendidikan anak prasekolah dewas ini, dimana terdapat kecenderungan bahwa pendidikan anak prasekolah merupakan pendidikan pendahuluan (opening) yang tidak dianggap terlalu penting dibanding dengan pendidikan anak pada tingkat dasar dan kelanjutan. Ini dibuktikan dengan banyak pendidikan anak untuk tingkat usia prasekolah yang disediakan dengan pola-pola yang terlalu sederhana menyangku peralatan belajar, media yang disediakan dan yang paling rendah adalah kualitas guru bagi anak prasekolah. Dalam kontek kelembagaan, hanya lembaga-lembaga dengan dana besar saja yang mempunyai perhatian serius tentang pentingnya pendidikan anak prasekolah sehingga mereka memenuhi dan menggunakan setandar pendidikan anak prasekolah dengan berbagai kebutuhannya.

b. Pandangan Ibn Qayyim Al-Jauzyyah tentang Peserta Didik

Dalam mendidik anak, tentunya kita tidak bisa lepas dari perbedaan individual. Selalu harus kita perhatikan potensi si anak, normalkah, superiorkah atau kurang dari normal. Dengan mengetahui potensi anak dan bakat-bakatnya, maka tujuan pendidikan anak dapat diarahkan sesuai dengan kemampuan untuk mencapainya. Pemikiran Ibn Qayyim tentang peserta didik dan adab-adabnya, perlu dijabarkan sebagai sebuah rumusan yang harus difahami secara menyeluruh oleh pendidik. Dalam kontek pendidikan anak prasekolah, ini merupakan bagian dari tanggung jawab pendidik untuk dapat menata secara sabar dan seksama, bagaimana anakanak dapat berkembang dengan baik baik di dalam lingkungan kelas maupun di luar kelas.

Baik dalam menentukan tujuan pendidikan sehubungan dengan perkembangan kemampuan intelektual, maupun sifat-sifat kepribadiannya, perlu diketahui potensi intelektual anak. Anak dengan potensi intelektual yang rendah, tidak dapat diharapkan bisa menarik kesimpulan dari pelajaran dan pengajaran dengan tepat dan cepat. Sebaliknya anak dengan kemampuan intelek tinggi, akan cepat mengerti dan mengambil manfaat dari apa yang diperolehnya. Sehingga menurut Ibn Qayyim guru benar-benar harus memahami dan mengetahui kondisi anak-anak dengan kemampuan dan potensi yang berbeda-beda.(Arif, 2010) 
Dalam kontek pendidikan anak prasekolah, anak-anak perlu dibimbing kepada sikap kompetitif dalam mencari ilmu dan mulai dikenalkan secara bertahap beberapa sifat yang harus dihindari oleh anak-anak. Yang paling baik adalah bagaimana anak-anak dibiasakan dengan pola-pola pergaulan yang bernilai Islami dan mencerminkan pada akhlak yang luhur. Anakanak juga perlu dibiasakan untuk dapat menjauhi tempat-tempat yang menyebarkan lahwun (kesia-siaan) dan tempat-tempat yang membawa kepada keburukan.(Al-Hijazy, 2001b)

\section{c. Tujuan Pendidikan Anak}

Tujuan pendidikan anak pada umumnya ialah menyediakan lingkungan yang memungkinkan anak didik untuk dapat berkembang dengan baik, sehingga ia dapat mewujudkan dirinya sebagai pribadi yang mandiri dan berfungsi sepenuhnya sesuai kebutuhan pribadi untuk tidak bergantung pada orang lain(Gustian, 2001).

Tujuan pendidikan anak dalam kontek ini tercermin dari sebuah konsep tertentu tentang pemeliharaan dan pembinaan anak yang dapat memberikan ruang yang cukup dan terarah bagi sebuah proses pertumbuhan dan perkembangan anak. Sehingga apa yang terjadi bagi pertumbuhan dan perkembangan anak akan sesuai dengan apa yang dicita-citakan, yaitu dapat memenuhi kebutuhan pengembangan bagi kemampuan dasar, bakat-bakat dan potensi-potensi yang dimiliki anak secara maksimal.

Sedangkan Ibn Qayyim Rahimahullah memandang bahwa tujuan (ahdaf) pendidikan yang utama adalah menjaga (kesucian) fitrah anak dan melindunginya agar tidak jatuh ke dalam penyimpangan serta mewujudkan dalam dirinya ubudiyah (penghambaan) kepada Allah Ta'la. Hal tersebut dikarenakan bahwa tujuan penciptaan manusia adalah untuk beribadah kepada Allah SWT. Dan oleh karenanya ibadah kepada Allah adalah fitrah seorang manusia(AlHijazy, 2001b).

Termasuk tujuan pendidikan yang hendak diwujudkan adalah: Pertama menanamkan akhlak mulia dalam diri anak didik dan menjauhkannya dari akhlak yang buruk. Kedua, menciptakan kebahagiaan dalam dirinya.(Hijazy \& Ali, n.d.) Ketiga, selalu memperhatikannya baik ketika mereka sedang tidur maupun ketika sedang berkomunikasi (berbicara). Keempat, mengarahkan cara berinteraksi dengan manusia lainya. Kelima, memperhatikan cara berpakaian yang baik. Keenam, mengarahkan bakat, mengembangkan kemampuan dasar anak, menyertainya dengan pendidikan agama, karena tanpa adanya pendidikan agama, anak-anak dihawatirkan terjerumus dalam penyimpangan di kemudian hari. Karena itulah, menurut beliau pendidikan agama seharusnya diberikan seimbang dengan tarbiyah mihaniyah (profesi dan keterampilan).

Dalam kontek pendidikan anak usia prasekolah, Ibn Qayyim Al-Jauzyyah menyoroti pentingnya orang tua dan pendidik untuk memperhatikan pendidikan anak dalam berbagai aspeknya. Sehingga dengan demimian anak akan terbentuk sebagai pribadi yang baik dalam hal mental, intelektual dan spiritual. Di dalam kitabnya Tuhfatul Maudud bi ahkamil Maulud, Ibn Qayyim Al-Jauzyyah memfokuskan beberapa tujuan pendidikan anak usia prasekolah sebagai berikut:

a) Menanamkan cinta kepada Allah dan Rasul-Nya pada diri anak semenjak usia dini, sehingga pada saat dewasa telah melekat dan menjadi bagian penting dalam dirinya.

b) Meningkatkan kesehatan akal dengan menjauhkan setiap sesuatu yang menakutkan dan mengagetkan mereka, karena hal itu akan berpengaruh pada akalnya.(Hijazy \& Ali, n.d.)

c) Memperhatikan masalah akhlak (tarbiyah khuluqiyah) dan membiasakan anak dengan kata-kata yang baik dan indah, terpuji, mencintai kebaikan dan jera terhadap keburukan, dan

d) Menjaga serta mengembangkan skill, kecerdasan dan jiwa anak, sehingga menjadi sosok yang mempunyai jati diri dan kepribadian yang kokoh.(Al-Hijazy, 2001a)

Pandangan Ibn Qayyim al-Jauzyyah tentang tujua pendidikan di atas implikasi pada pentingnya muatan aqidah dan akhlak dalam pendidikan anak usia prasekolah, tentu saja diartikan dengan memulai mengenalkan simbol-simbol akidah Islamiyah yang menjadi dasar dari keyakinan yang benar. Rasulullah SAW misalnya bersbada yang artinya, bukalah pembicaraan anak pada awal mereka dapat bicara dengan kalimat tauhid; La Ilaaha Illaallah. Sehingga upaya penanaman akidah dan keimanan menjadi tujuan yang penting dan perlu dirumuskan dengan jelas, agar anak-anak nantinya mempunyai pondasi yang kokoh tentang keimanan kepada Allah SWT dan rasulNya. 
Aspek-aspek Pendidikan Anak Usia Prasekolah menurut Ibn Qayyim Al-Jauzyyah Ibn Qayyim AlJauzyyah menyoroti beberapa aspek penting yang berkaitan dengan pendidikan anak usia prasekolah, tentu saja hal ini berkaitan erat dengan aspek psikologis dan merupakan kebutuhan dalam perkembangan anak yang harus dipenuhi secara baik dan maksimal.

Beberapa pandangan Ibn Qayyim Al-Jauzyyah tentang aspek-aspek pendidikan anak usia prasekolah, sebagai berikut:

i) Aspek Spiritual (Tarbiyah Imaniyah)

Islam memandang bahwa anak lahir dalam keadaan fitrah dan secara fitrah anak lahir membawa ke-Islaman dan ketauhidan, serta potensi-potensi sebagai makhluk da hamba Allah SWT. Sejalan dengan potensi dasar yang dimiliki anak, maka pendidikan yang diberikan pada anak secara perioritas diarahkan pada upaya melestarikan dan menumbuh-kembangkan aspek kefitrah-an tersebut (Tarbiyah Imaniyah), sehingga pendidikan untuk anak tidak kehilangan makna dan tujuan yang pokok dan mendasar, yaitu menjadikan hamba yang iman dan taat kepada Tuhannya.

ii) Aspek Moral (Tarbiyah Khuluqiyah)

Kebutuhan anak yang paling mendesak untuk dipenuhi adalah pembinaan akhlak dan budi pekerti.(Baharits \& Hasan, 1996) Ibn Qayyim Al-Jauzyyah mengatakan dalam kitab tuhfatul maudud,(Al-Hijazy, 2001a) bahwa pendidikan memiliki peran yang sangat besar dan pengaruh yang kuat dalam pembinaan akhlak seorang anak (mutarabbi). Sebagaimana beliau juga menegaskan bahwa tarbiyah yang baik adalah yang menjadikan pelatihan dan pembiasaan sebagai cara untuk menanamkan akhlak mulia dalam jiwa anak. Lebih lanjut, beliau menegaskan bahwa penyimpangan dan perilaku yang terjadi pada diri anak adalah dikarenakan lemahnya pendidikan akhlak yang seharusnya diberikan pada masa awal masa kanak-kanak.(Hijazy \& Ali, n.d.)

iii) Aspek Fisik (al-Jismiyah)

Anak-anak berkembang sebagai individu yang utuh, menggunakan pengindraan, pikiran dan tubuh dalam beraktivitas. Perkembangan fisik anak pada usia dini tampak sangat jelas, dan melakukan tugas-tugas fisik serta menggunakan anggota tubuh untuk melakukannya sangat penting untuk membangun kompetensi anak. Ibn Qayyim al-Jauzyyah tidak berbicara lebih jauh tentang bagaimana aktivitas fisik diatur dan dirumuskan bagai upaya pengembangan kreativitas dan kompetensi anak usia prasekolah.

Pandangan Ibn Qayyim ini tampaknya lebih diarahkan pada aspek fisik itu sendiri dan lebih menitik beratkan pada perlunya memperhatikan aspek kesehatan bagi anak, yang pada gilirannya diyakini dapat berimplikasi pada upaya memaksimalkan aktivitas fisik anak dalam membangun kompetensi. Ia memandang layanan pendidikan anak usia prasekolah dapat mencakup pelayanan kesehatan dan latihan ketangkasan dan kekuatan fisik, hal ini dimaksudkan agar daya kreativitas anak dapat tumbuh dan berkembang dengan baik.

Pandangannya tentang kesehatan fisik anak dimulai dari komentarnya tentang pentingnya ASI bagi bayi. Bayi yang baru lahir hendaknya disusukan kepada orang lain, karena air susu ibu di hari pertama melahirkan sampai hari ketiga masih bercampur dan kurang bersih serta masih terlalu kasar bagi sang bayi, dan hal ini akan membahayakan sang bayi.(Al-Hijazy, 2001a)

iv) Aspek Sosial (al-Tarbiyyah Ijtimaiyyah)

Anak-anak tumbuh dan berkembang paling baik dalam lingkungan yang tertib dan teratur, jauh dari hal-hal yang tidak baik. Mereka mengharapkan suatu yang baik dan indah, walaupun dalam kenyataannya anak-anak tanpa kompromi akan menelan semua yang dilihat dan didengarnya sekalipun buruk. Sehinggga Ibn Qayyim memandang bahwa hendaknya anak-anak tidak dibiarkan berinteraksi dengan orang-orang yang tidak jelas akhlak dan perilakunya, dan dijauhkan dari sikap berlebihan dalam berbicara, makan dan minum, kebebasan bergaul dan berteman,karena tindakan semacam itu akan menimbulkan kerugian dalam diri anak dan 
berdampak pada hilangnya potensi dan kemampuan dasar yang dimiliki oleh anak.(Al-Hijazy, 2001b)

Dalam kontek pendidikan anak prasekolah, Ibn Qayyim mengakui bahwa keterlibatan lingkungan bagi pertumbuhan dan perkembangan anak di masa itu adalah sangat besar. Sehingga lingkungan yang baik memiliki pengaruh yang besar terhadap pembentukan keperibadian dan watak seorang anak. Pergaulan yang buruk misalnya dapat membawa anak pada sikap perilaku amoral yang timbul dengan pola perilaku negatif yang bermacam-macam. Melalui pergaulan dan pertemanan inilah dampak buruk dapat secara cepat menghinggapi dan meracuni jiwa anak-anak. Pola perilaku dan lingkungan pergaulan yang negatif cenderung sangat mudah diperoleh anakanak melalui pergaulan bebas. Oleh karena itu, sangat penting mengupayakan agar anak mendapat lingkungan yang baik dan aman.

v) Aspek Mental-Intelektual

Pertumbuhan dan perkembangan anak tidak hanya dilihat berdasarkan aspek fisiknya saja, melainkan juga dalam kemampuan mental intelektualnya. Dengan semakin bertambahnya kemampuan anak secara fisik, anak akan mengekplorasi lingklungan dan menyerap informasiinformasi yang akan membantu perkembangan mental-intelektualnya. Ibn Qayyim al-Jauzyyah memandang bahwa pada usia (terutama dimulai usia 5 tahun) ini secara intelektual anak-anak telah sempurna akalnya dan dapat dipercaya pembicaraannya.(Hijazy \& Ali, n.d.)

Oleh karena itu Ibn Qayyim al-Jauzyyah menilai pentingnya memperhatikan pembinaan dan pemeliharaan daya intelektual anak pada usia prasekolah. Dalam pandangannya, pola pikir seseorang dapat terbentuk dari sebuah proses interaksi dengan lingkungan sekitar sehingga kesankesan negatife yang didapat oleh anak dari lingkungan sekitarnya, secara otomatis dapat menodai dan merusak pikirannya. Oleh karena itu dalam kontek pendidikan anak prasekolah ini beliau menganjurkan agar anak-anak dapat dijaga dan dihindarkan dari hal-hal yang bersifat negative dan kotor, baik berupa makanan, permainan ataupun lingkungan yang tidak baik, karena secara langsung atau tidak langsung dapat mempengaruhi pola piker dan kepribadiannya Ibn Qayyim Rahimahullah menyatakan sangat penting diperhatikan bahwa anak jangan sampai mendapati dan mengkonsumsi makanan dan minuman yang memabukkan (narkoba), yang membahayakan dan merusak akalnya, sehingga secara prefentif mereka harus dijauhkan dari komunitas pergaulan yang berpotensi dan dikhawatirkan akan merusak jiwanya. Mereka juga harus dijauhkan dari pembicaraan dan melakukan kontak dengan hal-hal yang merusak jiwanya, sebab hal itu dapat menjatuhkannya ke lembah kehancuran. Sangat mungkin, jika anak pernah melakukan perbuatan tidak baik tersebut, maka dalam hidupnya kelak, ia terbiasa dan penasaran dengan melakukan perbuatan yang tidak baik pula.(Al-Hijazy, 2001b)

\section{Kesimpulan}

Pemikiran Ibn Qayyim tentang pendidikan anak prasekolah adalah sangat bercorak normatif dan ia merupakan hasil kajian ulang terhadap pemikiran ulama-ulama terdahulu, dan cenderung bermuara pada nash-nash al-Qur'an dan Sunnah. Walaupun demikian dalam beberapa hal, secara kontektual, ia memberi penekanan yang tajam kepada pentingnya upaya sungguh-sungguh untuk kembali membangkitkan umat Islam dari keterpurukan. Hal ini tentu saja didasarkan pada kontek zamannya, dimana ia terlahir ditengah-tengah umat Islam yang sedang mengalami keterpurukan dalam berbagai bidang.

Pemikiran Ibn Qayyim tentang pendidikan anak usia prasekolah diarahkan pada upaya menyelamatkan fitrah dan potensi dasar yang dimiliki anak. Paling tidak ada 5 aspek yang menjadi tekanan dalam pendidikan anak usia prasekolah; Pertama, aspek mental-spiritual (al-Tarbiyyah alImaniyah), untuk menjaga fitrah ke-Tuhanan dan ke-Islaman anak. Kedua, aspek moral (al-Tarbiyah Khuluqiyah) sebagai bentuk tanggung jawab pendidikan moral, sebagai upaya membentuk pola perilaku anak ke arah al-akhlak al-karimah. Ketiga, aspek fisik (Tarbiyah Jismiyah) sebagai upaya memperhatikan aspek jasmaniyah. Keempat, Aspek sosial (al-Tarbiyah al-Ijtimaiyyah) diperlukan dalam menata lingkungan yang kondusif untuk mendukung perkembangan anak ke arah yang baik. Kelima, aspek Intelektual, ini menjadi bagian dari upaya pengembangan bakat dan potensi dasar yang dimiliki anak. Pada aspek keberbakatan diperlukan upaya pengembangan meliputi potensi-potensi akademis (shaheh alidrak dan jayyd al-hifd), inteligensi (husn al-fahm) dan ketangkasan yang dimiliki anak, dipersiapkan untuk menghadapi realita kehidupannya (musta'id lil al-furusiyah) di kemudian hari. Oleh karena itu, pemikiran yang penting dari Ibn Qayyim al-Jauzyyah tentang pendidikan anak prasekolah ini dapat dipertimbangkan untuk kemudian dijadikan sumber rumusan, konsep dan program pendidikan anak prasekolah. 


\section{Referensi}

Abdullah, M. (2010). Penggunaan Metode Tafsir bi al-Ra'y dalam Tafsir al-Manar: Satu Analisis. Perspektif: Jurnal Sains Sosial Dan Kemanusiaan, 2(1), 126-139.

Abidin, Z., Ushuluddin, D. J. A. F. F., \& Antasari, I. (2009). Peran Strategis Filsafat Islam dalam Pengembangan Kajian Psikologi Islam. Dalam Jurnal Ilmu Ushuluddin, 8(1).

Al-Hijazy, H. bin A. H. (2001a). Al-Fikrut Tarbawy Inda Ibni Qayyim.(terj. Muzaidi Hasbullah). Riyadh: Darul Hafidh Lin Nasyr Wa Tauzi.

Al-Hijazy, H. bin A. H. (2001b). Manhaj Tarbiyah Ibnu Qayyim, terj. Muzaidi Hasbullah, Jakarta Timur, Pustaka Al-Kautsar.

al-Jawziyyah, I. Q. (n.d.). Muhammad (2009) Uddat as-Sabirin wa Dhakhiratu ash-Shakirin. Patience and Gratitude), Makkah: Dar Alam al-Fawaid.

Aprianti, Y. (2016). PANDANGAN HUKUM KELUARGA ISLAM TENTANG PENGASUHAN OVERPROTEKTIF ORANG TUA TERHADAP ANAK DI DESA AIK MUAL KECAMATAN PRAYA KABUPATEN LOMBOK TENGAH. Mu'amalat: Jurnal Kajian Hukum Ekonomi Syariah, 8(1), 110-136.

Arif, Z. (2010). Konsep Pendidikan Islam menurut Ibnu Qayyim Al-Jauziyyah. IAIN Sunan Ampel Surabaya.

Badu, R. (2011). Pengembangan Model Pelatihan Permainan Tradisional Edukatif Berbasis Potensi Lokal dalam Meningkatkan Kemampuan dan Keterampilan Orang Tua Anak Usia Dini di PAUD Kota Gorontalo. Jurnal Penelitian Dan Pendidikan, 8(1), 70-77.

Badu, R. (2012). Pengembangan Model Pelatihan Permainan Tradisional Edukatif. Bandung: NQS KPAD.

Baharits, A., \& Hasan, S. (1996). Mas' uliyyah Li Abil Muslim fi al-Tarbiyah al-Walad fi al-Marhalati aththufullah diterjemahkan oleh Sihabuddin dengan judul Tanggung Jawab Ayah terhadap Anak Laki-Laki. Cet, I, Jakarta: Gema Insani Press.

Daya, B. (1990). Gerakan pembaharuan pemikiran Islam. Tiara Wacana Yogya.

Eprilia, U. H., \& Prasetyarini, A. (2010). Pelatihan Model-Model Pembelajaran Anak Usia Dini di Pos PAUD Kecamatan Delanggu, Kabupaten Klaten.

Fauzan, M. (2015). Analisis pendapat Imam Abu Hanifah tentang saksi buta dalam perkawinan. UIN Walisongo.

Gustian, E. (2001). Mempersiapkan anak masuk sekolah. Puspa Swara.

Hasyim, M. S. (2005). AL-ASY'ARIYAH (STUDI TENTANG PEMIKIRAN AL-BAQILLANI, ALJUWAINI, AL-GHAZALI). HUNAFA: Jurnal Studia Islamika, 2(3), 209-224.

Hijazy, A., \& Ali, H. Bin. (n.d.). Al Fikrut Tarbawy Inda Ibni Qayyim, diterjemahkan oleh Muzaidi Hasbullah dengan judul ". Manhaj Tarbiyah Ibnu Qayyim.

Jamaludin, M. A., \& Ramli, M. A. (2013). Al-Jallalah: Konsep dan Fatwa Semasa di Malaysia. Journal of Fatwa Management and Research, 252(1564), 1-26.

Katsir, I. (1996). al-Bidayah wa al-Nihayah. juz VII. Cet. I. Beirut: Dar Al-Fikr.

Keerthi, S. S., \& Lin, C.-J. (2003). Asymptotic behaviors of support vector machines with Gaussian kernel. Neural Computation, 15(7), 1667-1689.

Laela, D. P. (n.d.). PENDIDIKAN AGAMA ISLAM DAN KONTRIBUSINYA DALAM PEMBENTUKAN KEPRIBADJAN REMA. IA MUSLI. $M$.

Mujahidin, M. (2019). Hubungan Sosial Budaya Islam dan Kristen (Periode Pertengahan dan Modern). AL MA'ARIEF: Jurnal Pendidikan Sosial Dan Budaya, 1(1), 1-14. 
Munandar, U. (1999). Pengembangan kreativitas anak berbakat. Departemen Pendidikan \& Kebudayaan.

Murni, A., Nurul Yusra, T., \& Solfitri, T. (2010). Penerapan Metode Belajar Aktif Tipe Group to Group Exchange (GGE) untuk meningkatkan hasil belajar Matematika siswa kelas X IPS 1 MAN 2 Model Pekanbaru. Jurnal Penelitian Pendidikan, 11(2), 1-12.

Nurhaeni, T. (2008). Zuhud dalam pandangan IBN Qayyim Al-Jawziyyah.

Nurlela, E. S. (2009). Perceraian karena istri mandul (analisis putusan No. 1132/Pdt. G/2007/PAJS).

PAI, A. P. P. A. I. (1998). Pendidikan Agama Islam.

Rajab, M. A. (1961). Taammulat, Fi-Falsafah al-Akhlaq. Mesir: Maktabah Al-Anjalu Al-Mishriyah.

Smith, L., \& Raeper, W. (2000). Ide ide filsafat dan agama dulu dan sekarang. Kanisius.

Tanjung, S. (2011). FIQIH TARBAWI. Universitas Islam Negeri Sultan Sarif Kasim Riau. 